\title{
Obstacles to the educational praxis of nurses in the Family Health Strategy
}

\author{
Obstáculos para práxis educativa de enfermeiros \\ na Estratégia Saúde da Família \\ Obstáculos a las praxis educativas de enfermería \\ en la Estrategia de Salud Familiar
}

How to cite this article: Ferreira DS, Ramos FRS, Teixeira E, Monteiro WF, Aguiar AP. Obstacles to the educational praxis of nurses in the Family Health Strategy. Rev Gaúcha Enferm. 2021;42:e20190521. doi: https://doi org/10.1590/1983-1447.2021.20190521 aniversidade do Estado do Amazonas (UEA), Programa de Pós-Graduação em Enfermagem em Saúde Pública. Manaus, Amazonas, Brasil.

' Universidade Federal de Santa Catarina (UFSC), Programa de Pós-Graduação em Enfermagem. Florianópolis, Santa Catarina, Brasil.

c Universidade do Estado do Amazonas (UEA). Programa de Pós-Graduação em Medicina Tropical. Manaus, Amazonas, Brasil.

d Universidade do Estado do Amazonas (UEA) Programa de Residência em Enfermagem. Manaus, Amazonas, Brasil.

\section{ABSTRACT}

Objective: To analyze the obstacles to the educational praxis of nurses in the Family Health Strategy of the Eastern Health District, Manaus, Amazonas, Brazil.

Method: Qualitative, exploratory, and descriptive study that used the Word Café technique for data production, with 26 nurses, between June and August 2018. The data were organized in the Atlas.ti8 software, and the analysis was categorical-thematic.

Results: The units of analysis "Organizational Obstacles for Educational Praxis in the Family Health Strategy" and "Operational Obstacles for Educational Praxis in the Family Health Strategy" reveal difficulties, tensions, resistances and the impossibilities to adhere to emerging models of work organization, in general, and in particular, in educational work.

Conclusion: What presents itself in reality as an obstacle is, at the same time, indicative of the possibility of overcoming and potentiality for co-creation of educational work as a strategy to rescue professional motivation, and an alternative on the agenda for the permanent qualification of workers and institutions.

Keywords: Health education. Family Health Strategy. Community health nursing. Primary health care. Work.

\section{RESUMO}

Objetivo: Analisar os obstáculos para práxis educativa de enfermeiros na Estratégia Saúde da Família do Distrito de Saúde Leste, Manaus, Amazonas, Brasil.

Método: Estudo qualitativo, exploratório e descritivo. Para produção de dados utilizou a técnica Word Café com 26 enfermeiros, entre junho a agosto de 2018. Os dados obtidos foram organizados no software Atlas.ti8 e a análise foi de conteúdo categorial-temática.

Resultados: As unidades de análise "Obstáculos Organizacionais para Práxis Educativa na Estratégia Saúde da Família"e "Obstáculos Operacionais para Práxis Educativa na Estratégia Saúde da Família" desvelam: dificuldades, tensões, resistências e impossibilidades de adesão a modelos emergentes da organização do trabalho, em geral, e em especial, do trabalho educativo.

Conclusão: 0 que se apresenta como obstáculo, é, ao mesmo tempo indicativo de possibilidade de superação e potencialidade para co-criação do trabalho educativo como estratégia de resgate da motivação profissional, e alternativa de pauta na qualificação permanente dos trabalhadores e instituições.

Palavras-chave: Educação em saúde. Estratégia Saúde da Família. Enfermagem em saúde comunitária. Atenção primária à saúde. Trabalho.

\section{RESUMEN}

Objetivo: Analizar los obstáculos a la praxis educativa de enfermeros en la Estrategia de Salud Familiar del Distrito de Salud del Este, Manaus, Amazonas, Brasil.

Método: Estudio cualitativo, exploratorio y descriptivo que utilizó la técnica de Word Café para la producción de datos, con 26 enfermeras, entre junio y agosto de 2018. Los datos se organizaron en el software Atlas.ti8 y el análisis fue categórico-temático.

Resultados: Las unidades de análisis "Obstáculos organizativos para la praxis educativa en la estrategia de salud familiar" y "Obstáculos operativos para la praxis educativa en la estrategia de salud familiar" revelan dificultades, tensiones, resistencias e imposibilidades de adherirse a los modelos emergentes de organización del trabajo, en general y, en particular, el trabajo educativo. Conclusión: Lo que se presenta como un obstáculo es, al mismo tiempo, indicativo de la posibilidad de superación y potencial para la co-creación del trabajo educativo como una estrategia para rescatar la motivación profesional, y una alternativa para la calificación permanente de trabajadores e instituciones.

Palabras clave: Educación en salud. Estrategia de Salud Familiar. Enfermería en Salud Comunitaria. Atención primaria de salud. Trabajo. 


\section{口INTRODUCTION}

The educational praxis in health generates proposals that go beyond the search for changes in healthy behaviors and practices that contribute to the development of critical awareness, the exchange of knowledge and engenders the socialization of knowledge as a way to prevention, promotion and recovery health, founding premises of the work of the Family Health Strategy (FHS) teams. About this, it is known that when an educational practice intends to go beyond the information field and engage in a progressive perspective of human development, difficulties and obstacles need to be faced to achieve effectiveness in professional practices with/ between users and professionals in daily work in health ${ }^{(1)}$.

Studies have focused on the analysis of the work process in Primary Health Care (PHC), as well as on the perceptions, concepts, models, methods and techniques ${ }^{(1-3)}$. Brazilian scientific production has concentrated efforts on conducting evaluative studies on the effectiveness of PHC attributes ${ }^{(2)}$ (first contact, longitudinality, coverage/comprehensiveness and coordination of care) and regarding the improvement of access and quality of care ${ }^{(3)}$. The reach of new meanings of care, in the expanded perspective of the health-disease process and of mediation through education, imposes the search for evidence about daily practical obstacles and for alternatives to overcome and reframe the educational praxis itself. With this commitment, this study asked: what obstacles are present in the educational praxis of nurses in the Family Health Strategy of the East Health District, Manaus, Amazonas?

Regarding the pertinence of the study of educational praxis in the ESF in the scope of the city of Manaus, when addressing the obstacles and their connections with the educational praxis underway, one sees not only unveiling the local problem, but expanding the discussion and national production on the thematic, with emphasis on the relevance and role of FHS nurses in educational praxis. The protagonism is pointed out as fundamental for the achievement of the goals of the United Nations, especially with the Sustainable Development Goals (SDGs), which presupposes quality of performance, investment in formation of skills throughout life and professional valorization. In global terms, the importance of nursing is emphatically related to the potential of advanced nursing practices, to universal access and coverage to health services, with qualified and people-centered services ${ }^{(4)}$. Such potentials, however, cannot be isolated from educational practice and the dichotomies between clinical and educational practices, individual and collective, are unsustainable.
The study starts from the premise of the relevance of the professional performance of nurses for the realization of $\mathrm{PHC}$, the indispensability of health education and the need to better understand the reality of nurses' work. Thus, this study analyzes the obstacles to the educational praxis of nurses in the Family Health Strategy of the Eastern District of Health, Manaus, Amazonas. The term "praxis", adopted, contemplates the inseparability of theory and practice, that is, when exploring "the practices", it seeks to capture concrete subjects in action and transformation, integrating reality and thinking, objective and subjective $e^{(5)}$.

\section{METHODS}

Qualitative, exploratory and descriptive study. It takes as source the significant conversations of nurses about their work contexts through a dialogical and participatory strategy, in which FHS professionals are actors in the process of reflecting on praxis, unveiling obstacles in the daily care of families' health. The study took place from June to August 2018 at the Health Care Network (HCN) in Manaus, capital of the state of Amazonas, with the Eastern Health District (EHD) as its scenario. EHD, one of the five Districts linked to the Municipal Health Office (MHO), at the time of the study, had $55.14 \%$ of Primary Care coverage, 32\% of FHS and 241 active teams, according to the e-Gestor portal and the National Registry of Health Establishments (NRHE). EHD, during the study period, had 58 FHS teams with 37 nurses working in Units with different team formats and physical structure.

In this study 26 nurses participated in the EHD Basic Family Health Units (BFHU). The inclusion criteria were: be an effective professional at $\mathrm{MHO}$, have a minimum performance of two years in the same BFHU and be active during the period of data collection. Losses of follow-up in the study were considered when nurses were absent from the meetings and/or partially participated in a data collection session.

The data were produced using the group technique World Café, created in 1995 in California, United States of America by Juanita Brown and David Isaacs( ${ }^{(6)}$. It is a global conversation movement, with practitioners from the organizational and business scenario on six continents. In Brazil, it has been used as a research strategy in the Graduate Programs of the Aurora de Afonso Costa Nursing School (EEAAC) of the Universidade Federal Fluminense (UFF) in the thematic of Health Education, and by the Center for Studies in Innovation, Management and Information Technology (IMIT) of the Universidade Federal de Santa Catarina (UFSC) on the thematics of the Generation of Ideas, Products and Processes, 
within the scope of the Graduate Program in Engineering and Knowledge Management.

The World Café technique brings an approach to strategic dialogue, engagement, multigenerational collaboration and cooperative action adopted in multinational corporations, government agencies, educational institutions, community and non-profit organizations. It seeks to promote the discovery and participatory construction of joint solutions to collective problems, by meeting people around meaningful and strategic conversations. In these spaces, conversations favor exploring meanings for the multiple contexts of life and work $^{(6)}$.

Two meetings, with an average duration of 3 hours, were held in a commercial space (coffee shop) previously reserved, located in the southern area of the city of Manaus. In meetings, conversations favor exploring meanings for the multiple contexts of life and work ${ }^{(6)}$. The meetings were filmed and photographed. 12 and 14 nurses participated, respectively, in the first and second meetings.

The World Café technique application was coordinated and mediated by the host-researcher, who proceeded to raise the awareness of the participants through telephone contact followed by visits to EHD's BFHU. Participants were distributed in groups of four per table, with one of them having the role of table host. Support materials were provided, such as paper towels and pens for notes and recording of the ideas discussed and synthesized. The dialogues were organized in 15 minutes rounds, with the exchange of table participants each round, except for the host who did not move. The return to the initial tables took place in the last round with a summary of the findings (dialogues and records of towels) and sharing in plenary. Sharing is the opportunity to express collective knowledge.

On average, the duration was three hours, and to capture the speeches and all movement of production generated with the conversation, an audiovisual resource for filming the meetings was used. In order to contribute to logistics, records, frequency control and other aspects of infrastructure, duly trained research assistants participated and the meetings were photographed.

For the organization and processing of data, the contents of the tablecloths and videos were fully transcribed, in order to articulate the 3 sources: (i) notes and records written on the paper towels, (ii) filming of the oral explanations of the representatives of each table and reflections of the participants in plenary; (iii) records of researchers and assistants who observed the conversations at the tables. The data were processed using the software Atlas.ti 8 (Qualitative Research and Solutions) version 8.3.20/2019 using a single corpus transcription and coding process, for convergence of the research codes and generated units. This is a CAQDAS (Computer Assisted Qualitative Data Analysis Software) widely used in qualitative investigations in the most diverse areas and different theoretical and methodological approaches. This technological resource contributes to the rigor and scientificity in the interpretation of meanings, facilitating the handling in the process of organizing a large amount of data, both textual and imagetic. The use of the Atlas.ti 8 software was combined with the analysis of categorical-thematic content to understand the speeches and their meanings.

The discursive data transcribed generated a corpus of analysis, that is, a Hermeneutic Unit (HU) with two Primary Documents (PD), one for each Word Café performed. The categorical-thematic content analysis proceeded to codification, and the documents generated six Codes (Research Codes - RC), related to 163 discursive segments-expressions grouped by the sense-meaning. The codes were treated, and, in the process of (re)coding by association, interpretation and grouping, they generated two Code Groups, denominated Units of Analysis (UA).

The study received institutional approval from $\mathrm{MHO}$ and was approved by the Research Ethics Committee under CAAE 796719170.0000.5016 and statement No.2,376,273. The Free and Informed Consent Form and the Image and Voice Use Authorization Term were signed by the participants and researchers. The research subjects are supported by the ethical principles that rule research with human beings, social sciences and strategic interest with the Unified Health System (UHS).

\section{$\square$ RESULTS}

Six research codes were generated. Three of them were grouped in the Analysis Unit called Organizational Obstacles for Educational Praxis in the FHS, and the other three in the Operational Obstacles for Educational Praxis Unit in the FHS. Although the ergology framework is not specifically adopted, it shares the understanding of work organization from more general, visible and institutional components and operationalization from others that are less visible or normatively anticipated. The first, ergology assumes the "prescribed" dimension and was categorized as "organization". The seconds, included as "real work" by ergology (7), were treated as "operational" aspects. In summary, although the work's operability can be conceived within the organizational dimension, here these categories are distinguished, and the "organizational" unit of analysis should express aspects of formal and institutionally recognized management, or to roles commonly attributed to nurses (such as management of materials and infrastructure). The "operational" unit, on the 
other hand, results from the daily details or ways not always apparent to make the work happen, but experienced in relationships, confrontations and demands for creation that go beyond the normative.

Chart 1 shows the Units of Analysis, their respective codes and the magnitude according to the number of discursive segments that compose them.

In the first Unit of Analysis - Organizational Obstacles for Educational Praxis in the FHS - three research codes reveal elements linked to structural, material difficulties and the relationship with district and municipal management. In this unit, obstacles are listed to the elements necessary for organization, execution and implications for educational work.

Research code 1 highlights the difficulties with management and the lack of support as an element linked to the requirement to carry out activities without the necessary support for full execution. This code also enunciates the lack of constructive collective spaces between FHS teams and managers, as well as the focus on health promotion and education actions according to calendar, color and age group.

Unfortunately, we do not feel support from our superiors. There is a lot of demand and we can't get this support, so we can't improve on our own, there is always more demand and less support, and we really need support (Nurse 1. Verbal information).

We don't even have a meeting anymore, everything was taken away, now it's an administrative, informative meeting, there is no longer that meeting to discuss our problems. So, this kind of thing makes it difficult to plan the team, because we have other demands (Nurse 2. Verbal information).

The inversion that was made in the attendance structure, in service flow, how many times we have resistance to changes, but resistance is always thinking about how important this is for the needs of our community and not just for the flow of services (Nurse 3. Verbal information).
As the unit's service is also no longer by population group or program, this deconstructs. We end up not having time to work on this, why? Because we are following a schedule that is of a whole, like "October is for women", "November is for men", so everyone goes to work only for the woman that month and the man for the next and forgets the rest (Nurse 4. Verbal information).

The difficulties with the physical structure reveal the different team formats and physical structure of the family health units, the unavailability of physical space necessary for health education group activities, as well as the lack of adequacy of the physical structure for execution (or not) of collective educational actions.

Our reality is: we have the small house, the big house, mine is a strategy, we have three teams. So, everything is a different reality (Nurse 5. Verbal information).

We have no space, we work in a small house, it is very small, the new public policies also come up against the adequacy of the structure (Nurse 6. Verbal information). It is necessary to expand the physical space, those who work in very small units already know, they cannot do anything about education, so this type of thing makes it very difficult to do group work because we have a lot of demand (Nurse 7. Verbal information).

The strategies that we presented here come up against a lot in the lack of physical space that we don't have to work (Nurse 8. Verbal information).

The elements of the research code 3 express the difficulties experienced in the teams' daily lives, and articulate doing to the existence of necessary inputs for educational activities, such as folders, serial albums and educational support subsidies necessary for the feasibility of methods and techniques for beyond the voice and presence of the target audience.

\begin{tabular}{|c|c|c|c|}
\hline $\begin{array}{l}\text { HU/ } \\
\text { PD }\end{array}$ & RESEARCH CODES - RC & UNITS OF ANALYSIS - UA & Magnitude \\
\hline \multirow[b]{2}{*}{$01 \mathrm{HU} / 02 \mathrm{PD}$} & $\begin{array}{l}\text { 1. Difficulties with management } \\
\text { 2. Difficulties with physical structure } \\
\text { 3. Difficulties with inputs }\end{array}$ & $\begin{array}{c}\text { Organizational Obstacles for } \\
\text { Educational Praxis in FHS } \\
\text { (OOB-PFHS) }\end{array}$ & $\begin{array}{c}77 \\
\text { Segments }\end{array}$ \\
\hline & $\begin{array}{l}\text { 4. Difficulties with/between the team } \\
\text { 5. Difficulties face of contradictions in } \\
\text { work organization } \\
\text { 6. Difficulties to create and innovate }\end{array}$ & $\begin{array}{c}\text { Operational Obstacles for Educational } \\
\text { Praxis in FHS } \\
\text { (OPO-PFHS) }\end{array}$ & $\begin{array}{c}86 \\
\text { Segments }\end{array}$ \\
\hline
\end{tabular}

Chart 1 - Units of Analysis of obstacles for Nurses'Educational Praxis at FHS, Manaus, Amazonas, 2019 Source: World Café - Corpus of Video Transcriptions and Tablecloths 
I need support, materials, for example: "I have to have a folder" or "I have to have a space". I have to have a logistic that will not let me miss these things (Nurse 9. verbal information).

We do a round of conversations, exchange experiences, learn new techniques and even apply, but only apply the techniques that need of nurses, of speech, because if you need something else, we have to buy, because the district will not to send, even because they don't have it (Nurse 10. Verbal information).

There are even issues that I need to address, but the lack of support material, and even of time makes us give up on meeting this need, so we end up leaving it to school and the parents to work with them (Nurse 11. Verbal information).

In this current conjecture, it is not at all easy to ask for materials for group educational activities, in addition to not having it, the service is all mixed up, so how am I going to develop a theme and address it to a mixed clientele? (Nurse 12. Verbal information).

In the second Unit of Analysis - Operational Obstacles for Educational Praxis in the FHS - discursive elements were identified that describe human, relational and creative difficulties in the educational work process.

Difficulties with/among the team (research code 4) are shown as a critical operational element, with impacts on interpersonal relationships and, consequently, in the division of labor, overload, in the untapped potential for interprofessionality and knowledge sharing. Such obstacles limit the development of the team and the quality of the work developed.

It will depend a lot on the team we work on, the team we have. It's great when you have a good team (Nurse 13. Verbal information).

It is praiseworthy, when you find a qualified team, that you transmit the knowledge and they manage to acquire that knowledge of yours and transmit it to the community, because then you can redistribute the work (Nurse 14. Verbal information).

So, what I can observe is that the team is already used to it, accommodated with "everything has to be the nurse" or "I won't do it because I don't know how to do it" (Nurse 15. Verbal information).

My team goes through these difficulties, I have already found medical records that the CHA does not record anything, does not even know what he approached during the visit (Nurse 16. Verbal information).
We need more human resources (Nurse 17. Verbal information).

I also have to qualify my team to be helping me (Nurse 18. Verbal information).

Research code 5, difficulties in face of contradictions in the organization of work, translates the daily work of nurses in the FHS and the multiple tasks that overload the protagonism in front of the team and compromises the educational role within the volume of actions and practices linked to the district and the Municipal management itself. The reports show an understanding of the importance of educational actions, however, they highlight a conflict between educational practices and the agenda/programming as actions performed in isolation.

We talk so much about the difficulties, but, for example, everything is planned, material, space, team, then comes measles and stop everything, we solve it, start over, here comes H1N1, stop everything again, do you know why? Because everything is strategy, I doubt that it happen in medium complexity (Nurse 19. Verbal information).

And for that, everything has to be the nurse, that's why helives overwhelmed, stuck in bureaucracy and without time for promotion and education (Nurse 20. Verbal information).

It is true, it is one nurse for many programs, for many things and we are unable to do our own work (Nurse 21. Verbal information).

We no longer have this freedom to plan our activities, now everything is scheduled. I even want to reach a certain type of information with an audience in the community, but I can't the current agenda doesn't favor (Nurse 22. verbal information).

The difficulties to create and innovate (research code 6) highlight the tensions faced by nurses in the FHS in the set of activities, without increasing the creation and innovation of solutions for doing education in the FHS.

As he is a nurse for everything, we cannot stop and create something. The charge is the quantity and not the quality, so we have to produce and not think about creating something, and this spoils our work a lot (Nurse 23. Verbal information).

Because we can't create, we can only see the problem and try to find a solution to that problem, so how can we think of solutions if we don't create solutions we only live to solve problems (Nurse 24. Verbal information). 
The nurse is alone, he even wants to do everything, but he can't do it, he is overwhelmed with problems, and he can't see beyond (Nur25. Verbal information).

The discursive content of the results presents the most formal composition and structuring of educational (organizational) work, as well as the most everyday ways of operationalizing educational praxis in the FHS beyond the limits of formal organization. Synthetically, are unveiled difficulties, tensions, resistances and impossibilities to adhere to emerging models of work organization, in general, and in special, educational work.

\section{DISCUSSION}

The organizational and operational obstacles reveal structural, material and human aspects that interfere with the increase in the educational praxis of nurses in the FHS. Barriers are announced that impact and compromise the development of educational work with the community and the relationships between team members.

The difficulties with management deserve to be treated with in conjunction with the difficulties in the face of contradictions in the organization of work. Immediately they portray the content of the work carried out and its relation with the accumulation of activities, linked to the mode of production and the maximum productivity of goals, disconnected from the minimum conditions required for the functioning of the BFHU. Together, the categories show the fragmentation of educational praxis and the distance between planning and execution, in an intense dynamic between intentions and gestures within which the consolidation of the UHS aggravates issues related to the use of the work force and its wear, giving rise to the debate and reflection about the effectiveness of some professional practices and the relationship with workers' health ${ }^{(8)}$.

It is noted the existence of relations, sometimes of proximity, sometimes of distance between managers and FHS workers, as well as lack of knowledge and recognition of the reality of the dynamic work of nurses in the FHS and lack of collective spaces for observation and listening, which are fundamental participative instances for workers' expression and their capacity to think. The lack of collective spaces raises potential evidence of the inexistence, or insufficiency of relational technologies of listening and communication, which are essential operational elements for the work in the FHS. The National Humanization Policy (NHP), notably reception, constitute a strategic alternative to overcome difficulties and promote collective-educational work circumscribed in social valorization, in workers'experiences and in the possibility of becoming aware of the processes that subjects report, with a view to modifying the subjective relationship of workers and their practices ${ }^{(9)}$.

The hegemonic biomedical model centered on the disease crosses the family care model in the researched daily life and reveals itself as a hindering factor in the operationalization of the FHS, as a reordering of the health care model. This negatively implies the achievement of practices aimed at health promotion and education. The centralization in the disease, according to the participants, is based on the organization of work proposed by the management and perpetuates the practices of depersonalizing productivity of work and its psychodynamics ${ }^{(9)}$, which restricts the work to the sufficiency of care/procedures to the demand/offer of services by the teams to the users of the system ${ }^{(10)}$.

Reframing the meaning of the nurse's work in PHC is necessary and implies proposing new forms of management, division and reorganization of the modes of production of educational work in health services within the scope of the FHS. The emergence of new arrangements for strengthening promotion and education actions, qualifying access, available resources and responding to $\mathrm{PHC}$ attributes, as care coordinator and organizer of $\mathrm{HCN}^{(2-3)}$ are imperative.

Against some trends and strategies of work organization, workers want to resume scheduling by life cycle or health conditions in a movement to resist the recently implemented advanced access model. Advanced access practices have a quality effect on PHC services and minimize problems in the territory ${ }^{(11)}$, but success requires collective engagement and professional availability in readjusting praxis, changes in the organizational culture and in the working process, so that the resumption of scheduling does not cause regressions and impose barriers and restrictions on access to FHS teams. There are, however, severe criticisms of its negative effects, such as the drastic reduction of time for qualified care (quantity $x$ quality) and the subordination of planned activities, of care continuity, health education itself, and health promotion for the greater bond with the community, for example, to attending spontaneous demand ${ }^{(2,10)}$.

The presented outcomes point out to a current and emerging aspect, which refers to interpretive and critical freedom. Although, the restricted space and valorization of the educational dimension, have been highlighted for decades ${ }^{(10)}$, a new type of tension arises, between ways of prioritizing and responding to the needs of the population, since the work of nurses is increasingly required by the models of practice and advanced access or the expanded clinic in PHC. The justifications that support these models, such as the expansion of the resoluteness of clinical practice, based on the protocols and use of the International Classification 
for Nursing Practice (ICNP) (12), are not questioned. But, without working conditions and adequate team composition, changes were seen, in the context studied, as "undress a saint to dress another".

The incorporation of new tools or activities, such as reception and risk classification, are observed with hesitation as to applicability, training requirements and risk of uncritical assimilation, alienated from fundamentals, with an impact on work overload, workers' health and quality of attention ${ }^{(13)}$. What could be a potent work arrangement now means loss of autonomy, space, for health promotion actions, and bond with the territory, in addition to the clinic's activities.

It is necessary to relativize a narrative that reifies the recent past, on the other hand, as the one in which educational practices were possible. Thus, it is worth asking: (i) The idealization of a past model is has foundation in what experiences?; (ii) What are the implications of expanding the individual clinic and attending spontaneous demand in terms of requirements for the service (conditions) and for the professional (competences and profile)?; (iii) Is there a return to the old conflict between individual and collective actions?; Is there a possibility for health education within a model that favors individual attention?, (iv) Is it possible to think about health education in its multiple spaces and care dimension? The answers are beyond the limits of this study, but they warn the need for new studies and the construction of technologies that link (overcome the apparent distance) between clinical and educational practice.

Regarding difficulties with the physical structure, despite the governmental investments made, the reality of the study scenario is consistent with the rest of the country and reveals the existence of challenges in the typology of the physical structure of the Health Units ${ }^{(14)}$. The challenges include: inadequate, rudimentary and restricted physical structure, which limits the resolution of the actions developed by the team and translates the inadequate situation of the PHC physical service network and the difficulties of integration between the PHC and the other levels of health care, that negatively impact ongoing praxis and the guarantee of continuity of care ${ }^{(10,14)}$.

Manaus has Basic Health Units with a $32 \mathrm{~m}^{2}$ structure inherited from the implementation of the FHS in the municipality and which differs from the standards required by the National Primary Care Policy (NPCP). Even with the gradual replacement of the structure of these units, the facilities are a major obstacle to resolving the actions carried out by professionals and to the quality of services provided to users ${ }^{(14)}$. The alternative that enables the expansion and development of collective educational practices is the use of other equipment in the territory, such as: nearby and larger
BHU, churches, schools, community associations, among other intersectoral strategies.

With regard to material difficulties, collective educational practices within the PHC should respond to the needs of the territory, considering the vulnerabilities present in the area. It is important to use differentiated methodologies, centered on supported self-care and horizontal cooperation between users. Thus, it is important the shared constructed of the educational materials used and understand that they are not isolated pieces, but a complementary resource for educational actions of a participatory, critical and creative character ${ }^{(15)}$.

As for the pedagogical strategies, it is identified attempts at group, dialogical and participatory practices, which can be distinguished in an educational action based on the horizontal-collective axis ${ }^{(16)}$; but, against some trends related to the organization of educational work in health with a predominance of the use of individual practices, centered on persuasion and transfer of knowledge focused on pathologies and recommendations of behaviors with emphasis on illness, which characterizes an educational action of vertical-individual axis. It is necessary to consider that the "verticalized" approaches prioritize aspects such as risks, changes in habits and behaviors, clinical persuasion and prescription of practices, individual action, accountability of the subject, who must adjust to the conduct, which indicates an information-based educational praxis ${ }^{(16)}$. The "horizontalized" approaches, however, prioritize personal capacities and emancipation, change of reality, collective intervention, problematic and dialogic, an educational praxis based on training, needs, expectations, knowledges and values.

Verticalized approaches can be linked to the dominant hegemonic paradigm, which served the interests of the State until the 1970s. Horizontalized ones can be associated with the paradigmatic transition movement, which we started to build from the 1980s, which meet the fundamental principles of UHS and Freireans. The evalueted workers, however, perform activities of the vertical-individual axis with greater intensity, and at times experience, with less intensity, activities of the horizontal-collective axis. This outcome reinforces the (im)possibilities of educational action based on the collective and the dialogue, which has not translated the desired intensity in the world of practices.

Subjectivation based on normativity and homogenization $^{(10,14)}$, characterized by the little use of different strategies centered on the production of meanings and on the autonomy of the subjects of the praxis is verified. Studies reveal that educational praxis based on dialogical pedagogical practices, problematizing and considering the participants' experience, are considered adequate and potential in conducting 
an effective learning process. Thus, they contribute to the autonomy and empowerment of professionals and users, individually and collectively ${ }^{(17-19)}$.

The difficulties with/among the team constitute a challenging finding. Teamwork in the UHS context lacks strategies that enhance the engagement and co-responsibility of the professional with the work processes. This requires policies for the development of skills in the field of care, management and education. The National Policy of Permanent Education, in this sense, has not been effective in strengthening the FHS teamwork and the implementation constitutes a challenging element to the praxis with emphasis on the interprofessionality of actions guiding the logic of the user's health needs and complexity of the technical division of collaborative work among all team members ${ }^{(20)}$.

In light of the contradictions in the organization of work, initially discussed in relation to the difficulties with management, stads out the double role developed by the FHS nurse in the care and management dimensions, which is so present in PHC daily. The roles, even if dynamic, when disjointed and above posts distance the professional from the user and impair the collaborative interprofessional work centered on the person ${ }^{(20)}$. Professionals working in the FHS need to incorporate in their daily practices the culture of continuous assessment of processes, to jointly identify opportunities for improvement. This practice, when incorporated at the strategic, tactical-operational and operational level, gives co-responsibility and systematic and interdependent improvements in the educational praxis in the FHS.

Regarding the difficulties to create and innovate, the discursive content reveals the impossibilities of creation and innovation hampered by work overload. Nursing is the health profession with an increasing and excessive workload and impaired physical and mental integrity ${ }^{(21-22)}$. For the improvement of practices (by the institution and the collective) it is necessary to balance the loads and the institution of policies and practices that propose a continuous questioning of the praxis and point out new ways of dealing with the ongoing transformations, under the risk of the services repeating the exclusion (and illness) of care agents ${ }^{(23)}$.

The creativity and innovation are skills known to nurses. Inevitably, in a situation of overload, the ability to improve processes and/or invent new alternatives for solving problems within the scope of educational practice in the FHS is compromised. Innovation is an indispensable element in the improvement process of any organization and has an impact on overcoming limits and barriers in the work environment ${ }^{(24-25)}$.

In order to face the difficulties revealed in this study, as well as the promotion of collaborative, creative and inventive environments, the concept of stakeholders is chosen, as a network governance strategy that involves the stakeholders and makes use of the mediation of the actors and their different degrees of influence on the concreteness of the actions, without losing sight of the available resources. It is a successful model already used in two regions of the legal Amazon ${ }^{(26)}$ for the qualification of health work processes, in addition to a relevant participatory means of planning and implementation with strong adherence to information and communication technologies for a wide and inclusive reach of workers and users in actions (organizational and operational) of promoting education in health ${ }^{(10,14,24)}$.

\section{CONCLUSION}

The obstacles to the educational praxis of nurses in the family health strategy are in the scope of the organizational (management, physical structure, material) and operational (with/between the team, contradictions of work organization, limits to create and innovate). The results reveal difficulties, tensions, resistances and impossibilities to adhere to emerging models of work organization, in general, and in particular, educational work, although the outline of the investigated scenario can be considered a limitation of the research given its methodological design. Thus, expanded studies are suggested, in terms of multiprofessional teams and different regions of Brazil.

It is concluded that the real obstacle presented is, at the same time, indicative of the possibility of overcoming and potentiality for the co-creation of educational work, as a strategy to rescue professional motivation, and an alternative to be based on the permanent qualification of institutional bodies and workers.

The nursing worker wants the content of the work to be taken into account beyond the goals, he wants the escape from dehumanizing robotization and illness, but recognizes the goals as an isonomic tool so that the quantity is not the only indicator of productivity. The ways of doing educational work, however, lack of a privileged place in the planning and execution of health care. Therefore, the production mode must break the logic of fragmentation of work and be instituted and imbued as collective and transversal praxis for all members of the FHS teams.

\section{REFERENCES}

1. Nascimento AG, Cordeiro JC. Núcleo ampliado de saúde da família e atenção básica: análise do processo de trabalho. Trab Educ Saúde. 2019;17(2):e0019424. doi: https://doi.org/10.1590/1981-7746-sol00194

2. Lima JG, Giovanella L, Fausto MCR, Bousquat A, Silva EV. Atributos essenciais da Atenção Primária à Saúde: resultados nacionais do PMAQ-AB. Saúde Debate. 2018;42(esp 1):52-66. doi: https://doi.org/10.1590/0103-11042018s104 
3. Pinto LF, Giovanella L. The Family Health Strategy: expanding access and reducinghospitalizations due to ambulatory care sensitive conditions (ACSC). Ciênc Saúde Coletiva. 2018;23(6):1903-14. doi: https://doi. org/10.1590/1413-81232018236.05592018

4. Mendes IAC, Ventura CAA. Nursing protagonism in the UN goals for the people's health. Rev Latino-Am Enfermagem. 2017;25:e2864. doi: https://doi. org/10.1590/1518-8345.0000.2864

5. Costa R. A práxis marxista e o intelectual orgânico em Gramsci: a emancipação humana como horizonte. Germinal: Marxismo Educ Debate. 2020;11(3):23547. doi: https://doi.org/10.9771/gmed.v11i3.33635

6. Brown J, David I. 0 World Café: dando forma ao nosso futuro por meio de conversações significativas e estratégicas. São Paulo: Cultrix; 2007.

7. Oro J, Gelbcke FL, Sousa VAF, Scherer MDA. From prescribed work to the real work of nursing in in-patient care units of federal university hospitals. Texto Contexto Enferm. 2019;28:e20170508. doi. https://doi. org/10.1590/1980-265x-tce-2017-0508

8. Aciole GG, Pedro MJ. Sobre a saúde de quem trabalha em saúde: revendo afinidades entre a psicodinâmica do trabalho e a saúde coletiva. Saúde Debate. 2019;43(120):194-206. doi: https://doi.org/10.1590/0103-1104201912015

9. Conde AFC, Cardoso JMM, Klipan ML. Panorama da psicodinâmica do trabalho no Brasil entre os anos de 2005 e 2015. Gerais, Rev Interinst Psicol. 2019;12(1):19-36. doi: https://doi.org/10.36298/gerais2019120103

10. Soares AN, Souza V, Santos FBO, Carneiro ACLL, Gazzinelli MF. Health education device: reflections on educational practices in primary care and nursing training. Texto Contexto Enferm. 2017;26(3):e0260016. doi: https://doi. org/10.1590/0104-07072017000260016

11. Vidal T, Rocha S, Harzheim E, Hauser L, Tesser C. Scheduling models and primary health care quality: a multilevel and cross-sectional study. Rev Saúde Pública. 2019;53:(38). doi: https://doi.org/10.11606/s1518-8787.2019053000940

12. Kahl C, Meirelles BHS, Cunha KS, Bernardo MS, Erdmann AL. Contributions of the nurse's clinical practice to primary care. Rev Bras Enferm. 2019;72(2):354-9. doi: https://doi.org/10.1590/0034-7167-2018-0348

13. Costa AB, Gouvea PB, Rangel RCT, Scnheider P, Alves TF, Acosta AS. Percepção dos enfermeiros sobre 0 acolhimento e classificação de risco na Atenção Primária à Saúde (APS). Enferm Actual Costa Rica. 2018;(35):103-15. doi: https://doi. org/10.15517/revenf.v0i35.32113

14. Bousquat A, Giovanella L, Fausto MCR, Fusaro ER, Mendonça MHM, Gagno J, et al. Tipologia da estrutura das unidades básicas de saúde brasileiras: os 5 R. Cad Saúde Pública. 2017;33(8):e00037316. doi: https://doi. org/10.1590/0102-311x00037316

15. Santos ROM, Ramos DN, Assis M. Construção compartilhada de material educativo sobre câncer de próstata. Rev Panam Salud Pública. 2019;42:e122. doi: https://doi.org/10.26633/RPSP.2018.122

16. Teixeira E, Oliveira DC. Representações sociais de educação em saúde em tempos de AIDS. Rev Bras Enferm. 2014;67(5):810-7. doi: https://doi. org/10.1590/0034-7167.2014670520

\section{- Corresponding author:}

Darlisom Sousa Ferreira
17. Soares AN, Souza V, Santos FBO, Carneiro ACLL, Gazzinelli MF. Health education device: reflections on educational practices in primary care and nursing training. Texto Contexto Enferm. 2017;26(3):e0260016. doi: https://doi. org/10.1590/0104-07072017000260016

18. Ramos CFV, Araruna RC, Lima CMF, Santana CLA, Tanaka LH. Education practices: research-action with nurses of Family Health Strategy. Rev Bras Enferm. 2018;71(3):1144-51. doi: https://doi.org/10.1590/0034-7167-2017-0284

19. Barreto ACO, Rebouças CBA, Aguiar MIF, Barbosa RB, Rocha SR, Cordeiro LMM, et al. Perception of the primary care multiprofessional team on health education. Rev Bras Enferm. 2019;72(Suppl 1):266-73. doi: https://doi. org/10.1590/0034-7167-2017-0702

20. Rizio TA, Thomas WJ, O'Brien AP, Collins V, Holden CA. Engaging primary healthcare nurses in men's health education: a pilot study. Nurse Educ Pract. 2016;17:128-33. doi: https://doi.org/10.1016/j.nepr.2015.11.011

21. Peduzzi M, Aguiar C, Lima AMV, Montanari PM, Leonello VM, Oliveira MR. Expansion of the interprofessional clinical practice of primary care nurses. Rev Bras Enferm. 2019;72(supl. 1):114-21. doi: https://doi. org/10.1590/0034-7167-2017-0759

22. Oliveira BLCA, Silva AM, Lima SF. Carga semanal de trabalho para enfermeiros no Brasil: desafios ao exercício da profissão. Trab Educ Saúde. 2018;16(3):1221-36. doi: https://doi.org/10.1590/1981-7746-sol00159

23. Kabasakal E, Kublay $G$. Health education and health promotion skills of health care professionals working in family health centres. Int J Med Res Health Sci. 2017 [cited 2019 0ct 10];6(3):22-8. Available from: https://www.jimrhs.com/ medical-research/health-education-and-health-promotion-skills-of-healthcare-professionals-working-in-family-health-centres.pdf

24. Emerich BF, Onocko-Campos R. Formação para o trabalho em saúde mental: reflexões a partir das concepções de sujeito, coletivo e instituição. Interface (Botucatu). 2019;23:e170521. doi: https://doi.org/10.1590/Interface.170521

25. Feldman LB, Ruthes RM, Cunha ICKO. Criatividade e inovação: capabilities na gestão de enfermagem. Rev Bras Enferm. 2008; 1(2):239-42. doi: https://doi. org/10.1590/S0034-71672008000200015

26. Casanova A0, Giovanella L, Cruz MM, Ferreira MFDC. Atores, espaços e rede de políticas na governança em saúde em duas regiões de saúde da Amazônia Legal. Ciênc Saúde Coletiva. 2018;23(10):3163-77. doi: https://doi. org/10.1590/1413-812320182310.15442018

\section{Acknowledgments:}

To the Interinstitutional Doctoral Course between the Universidade Federal de Santa Catarina and the Universidade do Estado do Amazonas (Dinter PEN-UFSCUEA). The Municipal Health Department and Escola de Saúde Pública de Manaus (SEMSA-ESAP) and the Nurses of the Family Health Strategy of the Eastern District of Health of Manaus.
Email: darlisom@uea.edu.br

\section{Associate editor:}

Rosana Maffacciolli

Editor-in-chief:

Approved: 06.19.2020
Maria da Graça Oliveira Crossetti 